\title{
Water resources management: suggestions to the Brazilian model based on the American experience
}

\author{
L. B. E. Veiga \& A. Magrini \\ Energy Planning Program, \\ COPPE Federal University of Rio de Janeiro, Brazil
}

\begin{abstract}
Continuous population growth, increasing industrialization and expanding irrigated agriculture are all placing a strain on scarce water supplies, including serious depletion of aquifers.

To address this reality, in Brazil Law 9433, enacted in 1997, established the National Water Resources Policy and created the National Water Resource Management System, introducing a new integrated approach to environmental management policies through the application of economic-based instruments. This law defined the hydrographic basin as the unit of planning, considering multiple water uses, and introduced many changes at the institutional and policy instruments levels. However, nearly fourteen years after the enactment of this law, instead of integrated management and planning as originally envisioned, in many respects Brazil has returned to a strictly command and control approach. Evidence of this trend is the process of revising the rules on water quality standards and pollutant discharge limits by the federal environmental agency (CONAMA Resolution 357/2005). This process resulted in CONAMA Resolution 396/2008, which despite many criticisms maintained fixed limits for pollutant discharges, thus making no distinction between these discharges according to the related polluting activity or technology, or the carrying capacity of the natural water body.

The wisest course would have been to base the revision on the international water management experience. This article aims to contribute to this effort, by analyzing the case of the United States, which can provide valuable insight in terms of defining water quality standards and effluent discharge limits based on control technologies and industrial typologies. Some of the main water pollution
\end{abstract}


control instruments contained in the US Clean Water Act (CWA, 1948), which regulates water resource management in the U.S., along with the Code for Federal Regulation - CFR, Title 40 are analyzed in this paper. Among them are the Total Maximum Daily Load (TMDL) and the National Pollutant Discharge Elimination System (NPDES). Finally, based on the U.S. water resources management model, this paper makes some suggestions that could be incorporated in Brazilian legislation.

Keywords: water resources management, water quality, effluent discharges, Brazil, United States.

\section{Introduction}

The evolution of Brazil's institutional model on water resources management advanced greatly in 1997 with the enactment of Law 9433, which established the National Water Resources Policy and created the National Water Resources Management System. The law introduced important changes in the ways of managing environmental quality and resources. These changes are still being implemented today, with some inevitable adjustments. An initial analysis shows that today, fourteen years after the law took effect, this implementation still faces problems hindering the effective consolidation of the instruments set out by it. The law introduced five basic instruments necessary to put into operation actions for integrated management of water resources [1]. Among these was the classification of water bodies according to their main uses, aiming to establish mandatory water quality targets and the time frames for their achievement. The categories and environmental guidelines for classifying surface water bodies were defined in subsequent regulations, issued by means of Resolution 357, issued in 2005 by the National Environmental Council (CONAMA), which also established the conditions and standards for discharge of effluents [2]. However, these standards for discharge failed to consider the various types of discharging industries and the support capacity of the particular water bodies [2]. Because of these failings, various criticisms were made, prompting CONAMA to issue Resolution 397 in 2008 . The process of revising the rules is still continuing. An important contribution to this revision process would be the inclusion of instruments that have been established in other countries, especially the United States, which has a more advanced model of water resource management and pollution control. In light of the American model, this article presents some proposals that can be incorporated in the Brazilian case to make management of water resources more integrated and effective.

\section{Water resources management in Brazil}

\subsection{An Overview}

Brazil's 8,514,876 $\mathrm{km}^{2}$ of territory and over 190,000,000 [3] people in 2010 make it the fifth-largest country in the world in landmass and population. The country's continental dimensions, contrasting climates, population distribution 
and varied economic and social development, among other factors, result in wide differences between its geographical regions. It is estimated that about $12 \%$ of the world's surface water resources are located in Brazil [4]. In 2007, per capita water availability reached $43,027 \mathrm{~m}^{3}$ per year, above the world average of 8,209 $\mathrm{m}^{3}$ per capita in the same year [4]. For a long time, the notion of quantitative abundance supported a culture of water wastefulness and the postponement of investments necessary for more efficient use and protection of water resources. While some regions of Brazil, notably the semi-arid northeast, have always suffered water shortages, this supposed abundance in much of the country delayed realization of the importance of rational water use in some of Brazil's regions. The extremely uneven distribution of water resources is shown in Figure 1 , which compares water resources $\mathrm{x}$ surface area $\mathrm{x}$ population by percentage in the country's regions.

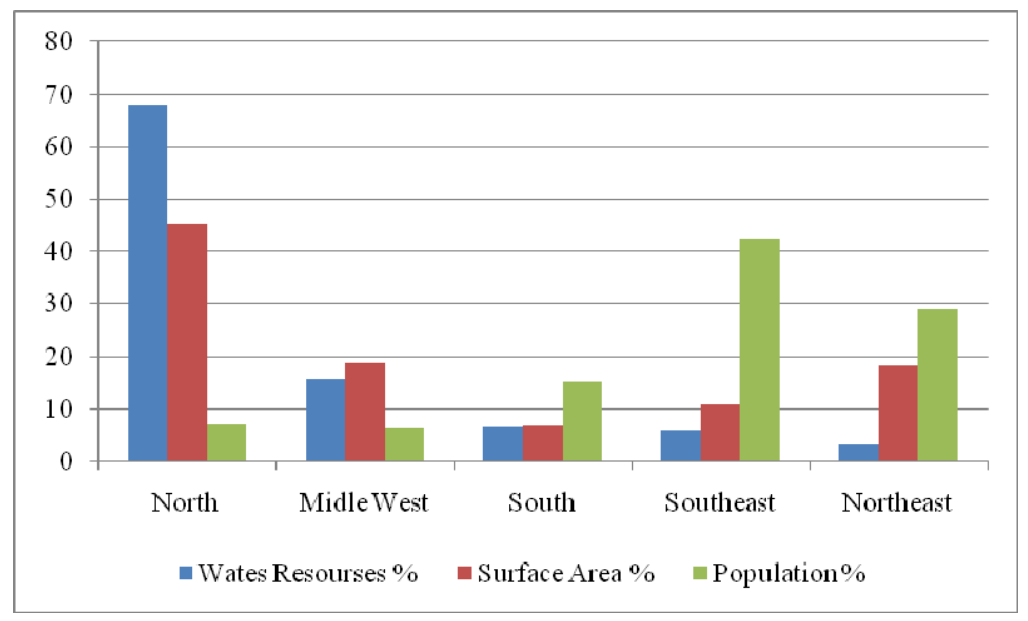

Figure 1: Water resources distribution among the Countries 5 Regions. Source: [4].

As the Brazilian National Water Agency (ANA) [4] explains, even though there is quantitative water abundance in some Brazilian states, there also is qualitative water scarcity. This qualitative scarcity derives mainly from a combination of excessive growth of localized demands (unplanned urban expansion, industrialization, livestock and farming expansion), which has resulted in the depletion of water resources, both in quality and quantity.

\subsection{The Brazilian water resources management model}

Brazil's first water resources management legislation, the Federal Water Code, was established in 1934. In 1988 a new Federal Constitution was promulgated. As defined by the Constitution, rivers and lakes can be the property of the federal government, when they flow through or border on more than one state, or a state government, when they are entirely within a single state. 
Nine years later, in 1997, after wide-ranging debates, the Brazilian Congress passed Law 9433, which established the National Water Resources Policy and created the National Water Resource Management System. Many changes were introduced at the institutional and policy levels [2]. The law defined the river basin as the territorial unit for water resources planning, breaking theoretically with the political-administrative division of the states. The law defined water as a public asset, scarce and endowed with economic value.

As Guimarães and Magrini [5] explain, Law 9433/1997 was innovative for the Brazilian water resource management model by: (a) introducing a new form of action in environmental policy; (b) decentralizing the water management approach; (c) defining river basin as the territorial unit for the implementation of the National Water Resource Policy and management of the National Water Resource System; and (d) adding a series of institutional and action changes.

From the policy instrument perspective, the law defined five management instruments and worked towards the integration of these instruments with the other instruments defined by the country's environmental legislation [1]. As defined by the law, these instruments are [6]:

- River Basin Plans, at three levels - federal, state and river basin: These define and identify management actions, plans, projects, works and investments that have priority for the watershed.

- Classification of water bodies according to their designated uses: This system establishes water quality targets to be met in a determined time frame. The water use classes are established by infra-legal regulations, particularly CONAMA Resolution 357/2005.

- Water permits: These allow the use of water for a determined period, seeking to assure the quantitative and qualitative uses of water. The permits are granted according to the use priorities defined in the water resource plan, to preserve multiple water uses and maintain the classification of the particular water body.

- Water charges: The purpose of these, besides raising revenue, is to send economic signals to society of the need for rational and sustainable water use, based on the principle that water is a common economic good. The money raised is earmarked for water management and conservation.

- Water resources information system: As the name suggests, this system gathers data on water resources, shedding light on their status and serving for studies of improvements.

At the institutional level, Law 9433/97 established a new organizational framework, the National Water Resource Management System, which involves shared ways of managing water [1]. The System as initially defined by the law was composed of the National Water Resources Board, State and Federal District Water Resources Boards, River Basin Committees and the River Basin Agencies. The River Basin Committees are the "center of gravity" of the System, as these committees are the venue for discussing use conflicts, always seeking participatory and decentralized management of water resources through the practice of continuous negotiation among the actors involved. In 2000, Law 9984 
created a new figure, the National Water Agency (ANA), responsible for the implementation and operationalization of the National Water Policy instruments.

In 2003, National Water Resources Board Resolution 32 divided the country into 12 hydrographical regions: Amazônica, Tocantins/Araguaia, Atlântico Nordeste Ocidental, Parnaíba, Atlântico Nordeste Oriental, São Francisco, Atlântico Leste, Atlântico Sudeste, Paraná, Uruguai, Atlântico Sul and Paraguai.

Besides the National Water Policy, each state is entitled to establish its own system for the water bodies contained completely within each state, as long as compatible with the federal rules and standards. As can be imagined, the establishment and implementation of these policies has varied widely depending on the states. This uneven implementation also applies to the 12 federal hydrographic regions, as can be seen in Table 1 .

Table 1: National water policy instruments implementation in the Brazil's 12 Hydrographical Regions.

\begin{tabular}{|c|c|c|c|c|c|c|c|}
\hline \multirow{2}{*}{$\begin{array}{l}\text { Hydrographical } \\
\text { Regions }\end{array}$} & \multirow{2}{*}{$\begin{array}{l}\text { River Basin } \\
\text { Committees }\end{array}$} & \multirow{2}{*}{$\begin{array}{c}\text { River } \\
\text { Basin } \\
\text { Agencies } \\
\end{array}$} & \multicolumn{5}{|c|}{ WRM Instruments } \\
\hline & & & 1 & 2 & 3 & 4 & 5 \\
\hline \multirow{3}{*}{ Atlântico Sudeste } & Doce & no & yes & no & yes & almost & no \\
\hline & $\begin{array}{l}\text { Paraíba do } \\
\text { Sul }\end{array}$ & yes & yes & yes & yes & yes & yes \\
\hline & $\begin{array}{l}\text { Pomba e } \\
\text { Muriaé }\end{array}$ & no & no & no & no & no & no \\
\hline \multirow{2}{*}{ Paraná } & PJC & yes & yes & no & yes & yes & yes \\
\hline & Paranaíba & no & almost & almost & yes & yes & yes \\
\hline \multirow{2}{*}{ São Francisco } & $\begin{array}{c}\text { São } \\
\text { Francisco }\end{array}$ & yes & yes & yes & yes & almost & no \\
\hline & $\begin{array}{l}\text { Verde } \\
\text { Grande }\end{array}$ & no & yes & almost & yes & no & no \\
\hline $\begin{array}{l}\text { Atlântico Nordeste } \\
\text { Oriental } \\
\end{array}$ & $\begin{array}{l}\text { Piranhas } \\
\text { Açu }\end{array}$ & no & no & no & yes & no & no \\
\hline Amazônica & no & no & no & no & no & no & no \\
\hline Tocantins/Araguaia & no & no & no & no & no & no & no \\
\hline Parnaíba & no & no & no & no & no & no & no \\
\hline \begin{tabular}{|l|} 
Atlantico Nordeste \\
Ocidental \\
\end{tabular} & no & no & no & no & no & no & no \\
\hline Uruguai & no & no & no & no & no & no & no \\
\hline Paraguai & no & no & no & no & no & no & no \\
\hline Atlântico Sul & no & no & no & no & no & no & no \\
\hline Atlântico Leste & no & no & no & no & no & no & no \\
\hline
\end{tabular}

Legend: 1- river basin management plans; 2- classification of water bodies; 3- water permits; 4- water charges; 5- water resources information system.

As can be seen from the table, in some hydrographic regions (Atlântico Sudeste, Paraná and São Francisco) most of the instruments have already been implemented, while in the others virtually no progress has been made. The 
country's uneven economic development and water distribution enter the picture here, because the three mentioned hydrographic regions are all located in more economically developed areas, areas of greater water stress. A combination of lack of urgency and/or lack of funds is responsible for the absence of significant progress in the other nine hydrographic regions.

\subsection{Water pollution control}

As mentioned, CONAMA Resolution 357/2005 sets the guidelines for classifying water bodies and the conditions and standards for discharging effluents from factories and farms. In this respect, the resolution implemented the overall policy established in Law 9433/97. The classification is the result of a planning process that establishes the quality level to be attained and/or maintained, considering the main uses and restrictions. The permits for water catchment and discharge of wastewater (including treatment requirements) are granted according to the classification of the water lake or river and its water quality standards.

Under CONAMA Resolution 357/2005, thirteen water classes were established: five for fresh water, four for brackish water and four for saline water [2]. Each class was defined according to the water quality required for the water body to comply with its designated use. The resolution also defined water quality standards (WQS) to be achieved and/or maintained in each water body segment. [2]. Each class was defined according to the water quality required for the water body to comply with its designated use. Regarding effluent discharges, the resolution established fixed limits for pollutant discharges, thus making no distinction between these discharges according to the related polluting activity or control technology, or the carrying capacity of the natural water body [2]. This inflexible control system attracted a good deal of criticism, as can be imagined.

Nevertheless, three years later, when CONAMA Resolution 395/2005 was revised by Resolution 397/2008, the problems of different types of polluting activities, control technologies and carrying capacity of the water bodies were not addressed [6]. No instrument aiming to integrate effluent discharges, water bodies' classification and water quality standards was established.

\section{Water resources management in the USA}

\subsection{The American water resources management model}

In the United States of America, the main Law concerned with water resources management is the Water Pollution Control Act, or Clean Water Act (CWA). Enacted in 1948, the CWA went thought several revisions. The CWA last major amendment occurred in 1987, which established a program for controlling toxic pollutant discharges and a program requiring states to develop and implement measures to control nonpoint sources of pollution [7]. Before the 1987 amendment the CWA only covered the control of individual pollutant sources. But the United States Environmental Protection Agency (EPA) along with the 
state authorities saw the need for greater control of non point sources, responsible for over $60 \%$ of the pollution of the country's water bodies [8].

The CWA is guided by a policy of federal-state partnership, where the federal government establishes the agenda and limits, while the states are tasked with implementing and overseeing enforcement of the determinations of the CWA [7]. The EPA is responsible for administering the programs and issuing the regulations and guidelines necessary to comply with the CWA.

The CWA provides water quality standards (WQS) for water bodies. According to Copeland [7] it is up to each state or territory to implement and establish these standards, which consist of the designated uses for the particular water body, the quality criterion and the anti-degradation policy [9, 10]. These standards must be submitted to the EPA for approval and take effect when the Agency declares them in conformity with the CWA.

Under the CWA, the effluent limits are defined for categories and classes of point sources. Even though the CWA did not say whether effluent limits should be set on a facility-by-facility basis or industry by industry basis, the EPA set industrial-wide guidelines for effluent limitations and technological standards for more than fifty major categories of industrial facilities [8]. These guidelines (CFR, Title 40, items 401 to 470) contain the limits on release of pollutants by categories of industrial facilities, which technological standards are drafted based on the level of reduction that can be attained by each category of industry, through the use of specific technologies defined by the EPA (CWA Best Practicable Technology - BPT or Best Available Technology - BAT) [11].

In establishing these guidelines the EPA considers two factors: (i) the performance of the best pollution control technologies or prevention practices that are available for a particular type of industry; and (ii) the economic probability of obtaining that technology, considering costs, benefits and the value of managing to reduce pollutant discharges [11]. The U.S. Environmental Protection Agency (EPA) is required by the CWA to periodically review and, if appropriate, revise effluent guidelines [11].

\subsection{Water pollution control}

In order to address and manage the pollution in American rivers and streams, the CWA defined two instruments: the Total Maximum Daily Load (TMDL) and the National Pollutant Discharge Elimination System (NPDES) [7]. Under CWA, American states must identify lakes, rivers, and streams for which effluent discharge limits are not stringent enough to achieve established water quality standards, after the implementation of technology-based controls by dischargers [12]. For each water body for which these limits are not stringent enough, the states are required to set a total maximum daily load (TMDL) of pollutants at a level that ensures that applicable water quality standards can be attained. According to Copeland [12], the TMDL is a pollution budget, a quantitative estimate of what it takes to achieve state water quality goals, setting the maximum amount of pollution a water body can receive without violating water quality standards, including a margin of safety. As Copeland [12] explains "A TMDL is both a planning process for attaining water quality standards and a 
quantitative assessment of problems, pollution sources, and pollutant reductions needed to restore and protect a river, stream, or lake". TMDLs addresses major pollution sources, including point sources such as municipal sewage or industrial plant discharges; nonpoint sources, such as runoff from roads, farm fields, and forests; and naturally occurring sources, such as runoff from undisturbed lands.

The TMDL is enforced by the States and the EPA through revisions to existing permits which include the pollutant limits and a schedule for compliance. It is worth to mention that the TMDL is one element of state water quality management programs. Other activities include standard setting, monitoring, permitting, and enforcement. Copeland [12] explains that throughout these years, most American states have lacked the resources to do TMDL analyses, which involve complex assessment in order to ascribe and quantify environmental effects for particular discharge sources. Only in 1992 did EPA issue regulations requiring states every two years to list waters that do not attain water quality standards and establish TMDLs [7]. Figure 2 presents the number of TMDLs implemented by all American states from 1996 to 2010.

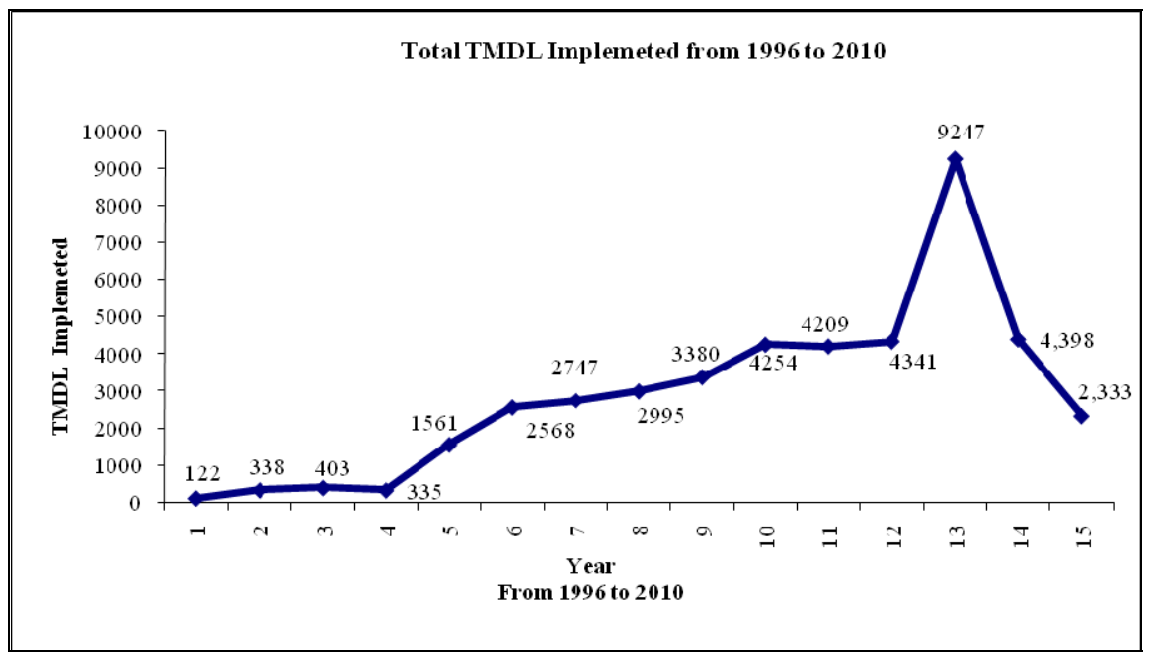

Figure 2: $\quad$ TMDLs implemented in the USA from 1996 to 2010. Source: [6].

Figure 2 reveals a major increase in the number of TMDLs implemented during these fourteen years. From 1999 to 2000, the number of TMDLs implemented increased 4.7 times. From 2007 to 2008, the number of TMDLs implemented doubled. According to Copeland [7], environmentalists see the TMDL as an important tool to achieving the overall goals and objectives of the act and to pressure EPA and states to address nonpoint and other sources of pollution which are responsible for many water quality impairments nationwide.

The second instrument of the American's water policy that should be mentioned is the National Pollutant Discharge Elimination System (NPDES), introduced in the CWA 1972 revision [13]. The NPDES regulates the discharge of pollutants into the U.S waters. Under the CWA the discharge of any pollutants 
through a "point source" into a US waters is not allowed unless it is authorized by an NPDES permit [13]. The NPDES controls water pollution by regulating point sources that discharge pollutants into US waters. In most cases the NPDES permit is administered by authorized states. The EPA decides on an appropriate numeric effluent limitation, based on its guidelines, considering if the pollution released by the source is toxic, conventional or non conventional, and based on what a specific technology can accomplish.

The CWA provided that effluent limitations for existent point sources should reflect the "best practicable control technology current available - BPT" and the "best available technology economic achievable- BAT" [13-15]. As Salzman and Thompson [8] explained: "sources are free to meet the effluent limitation in whatever manner they wish, however they usually adopt the technology suggested by the EPA to set the limitation in the NPDES because they know that the technology will allow them to meet the effluent limitation". Regarding new point sources, under the CWA they must meet effluent standards that reflect the "greatest degree of reduction the EPA determines to be achievable through application of the best available control technology (BACT), process, operating methods including, where applicable a standard permitting no discharge of pollutants $[14,15]$.

In 2003, the EPA issued the Water Quality Trading Policy (WQT), enabling the adoption of market-based approaches and the use of economic incentives for improving water quality and consequently reducing pollutant loads [16]. The policy acknowledges that the progress made towards restoring and maintaining the chemical, physical, and biological integrity of the country's waters under the CWA has been incomplete and that the WQT has the potential to achieve water quality and environmental benefits greater than would otherwise be achieved under more traditional regulatory approaches, at substantial economic savings [16]. Trading programs allow facilities facing higher pollution control costs to meet their regulatory obligations by purchasing environmentally equivalent (or superior) pollution reductions from another source at lower cost, thus achieving the same water quality improvement at lower overall cost. Where trading involves nonpoint sources, states should adopt methods to account for the greater uncertainty in estimates of nonpoint source loads and reductions.

The WQT is intended to encourage voluntary trading programs that facilitate implementation of TMDLs, reduce the costs of compliance with CWA regulations, establish incentives for voluntary reductions and promote watershedbased initiatives [17]. It supports trading to improve or preserve water quality in a variety of circumstances [17]. For example, in unimpaired waters, trading may be used to preserve good water quality by offsetting new or increased discharges of pollutants. In waters impaired by pollutants, trading may be used to achieve earlier pollutant reductions and progress towards water quality standards pending the development of a TMDL. And trading may be used to reduce the cost of achieving reductions established by a TMDL. According to the EPA website (accessed in January 2011), 25 states are currently in various stages of developing trading programs. 


\section{Conclusions}

The analysis of the water quality and effluent discharge limits in Brazil in comparison with those in the United States shows that Brazil is consolidating an extremely rigid control system, where the standards do not vary either by type of industry/activity and control technology or in function of the water quality and use designation of the receiving body. This inflexibility engenders an overvaluation of the command and control instrument by the various social actors, in detriment to a balanced and integrated view of environmental management by the various public authorities, oriented mainly by the support capacity of the environment. Besides being less effective in protecting the environment, this process imposes huge costs on the different public and private agents.

Therefore, in light of the American water resource management model, there are several improvements that can and should be incorporated by Brazilian legislation and regulations. However, three categories deserve special mention:

- Promotion of effective decentralization of water resource management, as occurs in the U.S. As mentioned, in the U.S. water resource management is guided by a policy of federal-state partnership, where the federal government establishes the agenda and limits while the states are tasked with implementing and overseeing enforcement of the legal determinations.

- Establishment of changes in the definition itself of the effluent discharge conditions and limits, which should first consider the type of industrial/agricultural activity involved and the applicable control technologies and practices, and second, should be linked through some instrument to the water quality standards of the receiving bodies. This link in the United States is accomplished through the Total Maximum Daily Loads (TMDL).

- Introduction in Brazilian water management legislation an instrument such as the Total Maximum Daily Loads (TMDLs), which can integrate effluent discharges, water bodies' classification and water quality standards, and also address uncontrolled sources of water impairment.

\section{Acknowledgements}

We thank Financiadora de Estudos e Projetos (FINEP), Fundação de Amparo a Pesquisa no Estado do Rio de Janeiro (FAPERJ) and Coordenação de Aperfeiçoamento de Pessoal de Nível Superior (CAPES) for the financial support making possible the development of this study. 


\section{References}

[1] Magrini, A. \& Santos, M., River Basin Management and the National Water Resources Policy in Brazil. In:. Brebbia, C.A; Anagnostopoulos, P., Katsifarakis, K. \& Cheng, A.H-D, (Org.). Water Resources Management. Southampton, v. 4, pp. 79-88; 2001.

[2] Magrini, A.; Szklo A.S.; Veiga, L.B.E.; Heniques, R.; Silva, R.G., “ A cross-sectional analysis of Brazil s effluent discharge regulation. In: Fourth International Conference on River Basin Management Including all aspects of Hydrology, Ecology, Environmental Management, Flood Plains and Wetlands, 2007, KOS, Greece.

[3] IBGE, Instituto Brasileiro de Geografia e Estatística, available at: http://www.ibge.org.br

[4] ANA - Agência Nacional de Águas, "Conjuntura dos Recursos Hídricos no Brasil”, ANA, Brasília, 2009.

[5] Guimarães, L., Magrini, A. "A Proposal of Indicators for Sustainable Development in the Management of River Basins", Water Resource Management, 22:1191-1202, DOI 10.1007/s11269-007-9220-x, December 2007.

[6] Elabras-Veiga, L. B., "Dez anos da Lei no. 9.433 de 1997: atual estágio de implementação e comparação com a Legislação Internacional de Gestão de Recursos Hídricos", Relatório de Pesquisa, Fundação de Amparo a Pesquisa no Estado do Rio de Janeiro - FAPERJ, RJ, Brasil, Setembro 2010.

[7] Copeland, C., "Clean Water Act: a summary of the Law", CSR Report for Congress 30030, USA, August 2008a.

[8] Salzman, J., Thompson Jr., B. H., "Environmental Law and Policy", Chapter 5, Water Pollution, p. 137-164, Foundation Press, USA, 2007.

[9] US-EPA, United States Environmental Protection Agency, "National Recommended Water Quality Criteria", Washington, D.C., 2006, available at: www.epa.org.

[10] US-EPA, United States Environmental Protection Agency, "Water Quality Standards Handbook " - Second Edition, Washington, D.C., 1994, available at: www.epa.org

[11] US-EPA, United States Environmental Protection Agency, "Technical Support Document for Effluent Guidelines Program Plan”, Washington, D.C., 2004, available at: www.epa.org

[12] Copeland, C., "Clean Water Act and Total Maximum Daily Loads (TMDLs) of Pollutants”, CSR Report for Congress 97-831, USA, 2001 and 2008b.

[13] Copeland, C., "Clean Water Act Section 401: background and issues", CSR Report for Congress 97-488, USA, August, 2008 c.

[14] US-EPA, United States Environmental Protection Agency, "NPDES Permit: Writers Manual, US-EPA, Washington, DC, December 1996, available at: www.epa.org. 
[15] US-EPA, United States Environmental Protection Agency, "Protecting the Nations' Waters through Effective NPDES Permit", A Strategic Plan for 2001 and beyond, Washington, DC, 2001, available at: www.epa.org.

[16] US-EPA, United States Environmental Protection Agency, "Water Quality Trading Assessment Handbook: Can Water Quality Trading Advance Your Watershed's Goals?”, Washington, D.C., 2004, available at: www.epa.org.

[17] US-EPA, United States Environmental Protection Agency, "Water Quality Trading Evaluation, Final Report: Through Evaluation Promoting Environmental Results", Washington, D.C., 2008, available at: www.epa.org. 